\title{
Evaluation of Micro Finance in Harda and Hoshangabad Districts of MP
}

\section{Roli Pradhan*}

Department of Humanities, MANIT Bhopal, India

\begin{abstract}
Microfinance is gathering momentum to become a significant force in India. The Self Help Group (SHG) model with bank lending to groups of (often) poor women without collateral has become an accepted part of rural finance. The paper discusses the state of SHG-based microfinance in India and the opportunity untapped because of the huge existing demand-supply gap. With traditionally loss-making rural banks shifting their portfolio away from the rural poor in the post-reform period, SHG-based microfinance, nurtured and aided by NGOs, have become an important alternative to traditional lending in terms of reaching the poor without incurring a fortune in operating and monitoring costs. The government and NABARD have recognized this and have emphasized the SHG approach and working along with NGOs in its initiatives. In spite of the impressive figures, the supply side of microfinance in India is still presently grossly inadequate to fill the gap between demand and supply but it holds the promise to act as a great opportunity for the financial sector and the economy as a whole. This paper evaluates the different aspects of microfinance in Harda and Hoshangabad districts of MP.
\end{abstract}

\section{Keywords: Microfinance; Finance; Rural finance}

\section{Indian Scenario}

Bank nationalization in India marked a paradigm shift in the focus of banking as it was intended to shift the focus from class banking to mass banking. The rationale for creating Regional Rural Banks was also to take the banking services to poor people. The branches of commercial banks and the RRBs (Regional Rural bank) have increased from 8321 in the year 1969 to 68,282 branches as at the end of March 2005. The average population per branch office has decreased from 64,000 to 16,000 during the same period. However, there are certain under-banked states such as Bihar, Orissa, Rajasthan, Uttar Pradesh, Chattisgarh, Jharkhand, West Bengal and a large number of NorthEastern states, where the average population per branch office continues to be quite high compared to the national average.

\section{Financial Inclusion and Micro Finance}

Microfinance is the provision of financial services to low-income clients, including consumers and the self-employed that traditionally lack access to banking and related services. In microfinance focuses on poor people and people which are still not use facilities of the bank. Financial inclusion is closely related with Microfinance because in financial inclusion is also concentrate on the people which belongs to low income group and make the advantage of that group to banking facilities available in today's scenario. From its inception in the 1970s, microfinance has evolved in astounding ways, incorporating into its practice social and economic development concepts, as well as principles that underlie financial and commercial markets. This combination has led to the creation of a growing number of sustainable microfinance institutions around the developing world. As microfinance continues to evolve as a development strategy, it will be successful only if it is able to strike the right balance between the two frameworks development and finance that underlie its practice. Financial inclusion is also about providing banking facilities at an affordable cost to the vast sections of disadvantaged and low income groups. It's a new emerging concept in Indian economy and very necessary for economy growth. Financial inclusion includes all the aspects of microfinance, so that it is closely related to the Micro finance.

State bank of India is one of the public sector bank which initiate in the financial inclusion in rural area and area where the banking facilities not reach yet. State bank of India is one of the largest banks in India which is growing day by day. The State Bank of India, the country's oldest Bank and a premier in terms of balance sheet size, number of branches, market capitalization and profits is today going through a momentous phase of Change and Transformation - the two hundred year old Public sector is today stirring out of its Public Sector legacy and moving with an ability to give the Private and Foreign Banks a run for their money.

The bank is entering into many new businesses with strategic tie ups - Pension Funds, General Insurance, Custodial Services, Private Equity, Mobile Banking, Point of Sale Merchant Acquisition, Advisory Services, structured products etc - each one of these initiatives having a huge potential for growth. The Bank is forging ahead with cutting edge technology and innovative new banking models, to expand its Rural Banking base, looking at the vast untapped potential in the hinterland and proposes to cover 100,000 villages in the next two years. It is also focusing at the top end of the market, on whole sale banking capabilities to provide India's growing mid / large Corporate with a complete array of products and services. It is consolidating its global treasury operations and entering into structured products and derivative instruments. Today, the Bank is the largest provider of infrastructure debt and the largest arranger of external commercial borrowings in the country. It is the only Indian bank to feature in the Fortune 500 list.

The Bank is changing outdated front and back end processes to modern customer friendly processes to help improve the total customer experience. With about 8500 of its own 10000 branches and another 5100 branches of its Associate Banks already networked, today it offers the largest banking network to the Indian customer. The Bank is also in the process of providing complete payment solution to its clientele with its over 8500 ATMs, and other electronic channels such as Internet

*Corresponding author: Roli Pradhan, Department of Humanities, MANIT Bhopal, India, E-mail: pradhanroli@gmail.com

Received April 19, 2013; Accepted July 29, 2013; Published August 01, 2013

Citation: Pradhan R (2013) Evaluation of Micro Finance in Harda and Hoshangabad Districts of MP. J Glob Econ 1: 103. doi:10.4172/2375-4389.1000103

Copyright: (C 2013 Pradhan R. This is an open-access article distributed under the terms of the Creative Commons Attribution License, which permits unrestricted use, distribution, and reproduction in any medium, provided the original author and source are credited. 
banking, debit cards, mobile banking, etc. The bank is also looking at opportunities to grow in size in India as well as internationally.

\section{Literature Survey}

In India, financial inclusion first featured in 2005, when it was introduced by KC Chakraborthy, the chairman of Indian Bank. Mangalam Village became the first village in India where all households were provided banking facilities. Norms were relaxed for people intending to open accounts with annual deposits of less than Rs. 50,000. General credit cards (GCCs) were issued to the poor and the disadvantaged with a view to help them access easy credit. In January 2006, the Reserve Bank permitted commercial banks to make use of the services of Non-Governmental Organizations (NGOs/SHGs), micro-finance institutions, and other civil society organizations as intermediaries for providing financial and banking services. These intermediaries could be used as business facilitators or business correspondents by commercial banks. The bank asked the commercial banks in different regions to start a $100 \%$ financial inclusion campaign on a pilot basis. As a result of the campaign states or U.T.s like Pondicherry, Himachal Pradesh and Kerala announced 100\% financial inclusion in all their districts. Reserve Bank of India's vision for 2020 is to open nearly 600 million new customers' accounts and service them through a variety of channels by leveraging on IT. However, illiteracy and the low income savings and lack of bank branches in rural areas continue to be a roadblock to financial inclusion in many states and there is inadequate legal and financial structure.

India has a long history of banking development. After Independence, the major focus of the Government and the Reserve Bank was to develop a sound banking system which could support planned economic development through mobilization of resources/deposits and channel them into productive sectors. The planning strategy recognized the critical role of the availability of credit and financial services to the public at large in the holistic development of the country with the benefits of economic growth being distributed in a democratic manner. In recognition of this role, the authorities modified the policy framework from time to time to ensure that the financial services needs of various segments of the society were met satisfactorily. The organized financial system comprising commercial banks, Regional Rural Banks (RRBs), Urban Co-Operative Banks (UCBs), primary agricultural credit societies (PACS) and post offices caters to the needs of financial services of the people. Besides, MFIs, self-help groups (SHGs) also meet the financial service requirements of the poorer segments. Furthermore, development of the institutional framework in recent years has focused on new models of expanding financial services involving credit dispensation using multiple channels such as Civil Society Organizations (CSOs), Non-Government Organizations (NGOs), post offices, farmers' clubs, and panchayat's as business facilitators/correspondents. Specific financial instruments/products were also developed. Financial inclusion in the Indian context implies the provision of affordable financial services, viz., access to payments and remittance facilities, savings, loans and insurance services by the formal financial system to those who tend to be excluded. Besides access, emphasis is also placed on affordability (low cost) of financial services such as savings, loan, and remittance to the underprivileged segments of the population. Although the term 'financial inclusion' was not in vogue in India then, since the late 1960s both the Government and the Reserve Bank have been concerned about the non-availability of banking facilities to the under-privileged and weaker sections of the society. Accordingly, several initiatives have been taken over time such as nationalization of banks, prescription of priority sector targets, lending to weaker sections at concessional rates, and initiation of the lead bank scheme. These initiatives were undertaken at different points in time to expand the outreach of banking facilities and increase the flow of credit to the rural areas. However, the broad approach towards financial inclusion followed in India in the 1970s and the 1980s was more oriented towards credit requirements of specific sectors/segments and there was relatively low emphasis on individual/household level inclusion.

Shetty [1] examined the promise of microfinance (institutions) programme in the (financial) inclusion of marginalized and vulnerable poor, who have been excluded from the formal credit markets for a long period of time and also defined that the welfare impact of "credit plus services" on the poor. Financial exclusion has its roots in social exclusion concluding the enhanced measures of financial inclusion which include both access and usage should be applied, since access and usage are not the same but supplementary [2]. An attempt has been made by Mandira and Jesim [3] to examine the relationship between financial inclusion and development. The paper first attempts to understand the relationship between IFI and the Human Development Index (HDI), the most widely used development index. The IFI is a multi-dimensional index that captures information on various dimensions of financial inclusion in one single digit lying between 0 and 1 , where 0 denotes complete financial exclusion and 1 indicates complete financial inclusion in an economy. The proposed index is easy to compute and is comparable across countries [4]. The Microfinance Review reveals the loans taken by the members from outside the SHG indicate that although as an alternative source of credit SHGs were able to fulfill the credit needs of the members to some extent; it was unable to fully satisfy their credit needs. Especially for higher amount of loans, members go either to the moneylenders or to the formal financial institutions [5] .The drive for financial inclusion in Gulbarga failed to bring large numbers of people into the ambit of formal finance. Nonetheless, we see that coupling government programmes with financial inclusion may greatly increase access to bank accounts and shows potential to increase usage as well [6]. Jovi et al. [7] described the conjectures of the study shall be tested from a set of international data on the microfinance industry and the findings verified for the Philippine case. Pokhriyal and Vipin [8] examined the progress of microfinance in terms of the successes and failures of SHG-bank linkage program and whether this program has reduced regional disparities. Dharen and Mukesh [9] mainly focused upon the achievements of the microfinance services towards financial inclusion. The role of every participant in the microfinance market has been analyzed. Bharat [10] examined the relationship between the level of indebtedness to moneylenders and the type of microfinance model. Study helping focus and initiate actions in correcting the structural/regional imbalances in microfinance programs. It would help in outlining policy imperatives at macro level for making microfinance as a vehicle of inclusive growth more effectively [11]. Christabell and Vimal [12] presented paper dealing with how the mechanism of microfinance can enable the financial inclusion of hitherto excluded population, especially the women, into the formal financial sector. Measuring Financial Inclusion Explaining Variation Across and Within Countries" paper summarizes the first global dataset of publicly available indicators that measure how adults in 148 countries save, borrow, make payments, and manage risk [13] "Workshop on Measuring Financial Inclusion from the Demand Side" 
aims to provide an opportunity for leading scholars, practitioners and policy makers to help define an agenda on financial inclusion from the demand side [14]. Vighneswara Swamy PM [15] has critically analyzed the issues and challenges involved in financial inclusion for inclusive growth and have also successfully attempted to highlight the factors that can aid in achieving financial inclusion for inclusive growth in India. The first analysis of the Global Financial Inclusion (Global Findex) Database provided by Demirgue [16] explained a new set of indicators that measure how adults in 148 economies save, borrow, make payments, and manage risk. The broad strategy for financial inclusion in India in recent years comprises the following elements:

- Encouraging penetration into unbanked and backward areas and encouraging agents and intermediaries such as NGOs, MFIs, CSOs and Business Correspondents (BCs)

- Focusing on a decentralized strategy by using existing arrangements such as State Level Bankers' Committee (SLBC) and District Consultative Committee (DCC) and strengthening local institutions such as co-operatives and RRBs

- Using technology for furthering financial inclusion

- Advising banks to open a basic banking 'no frills' account

- Emphasis on financial literacy and credit counseling

Various initiatives undertaken could broadly be categorized into three phases. In the first phase starting in the late 1960s through the 1980 s, the focus was on channeling of credit to the neglected sectors of the economy. Special emphasis was also laid on weaker sections of the society. In the second phase spanning the early 1990s through March 2005, the focus was mainly on strengthening the financial institutions as part of financial sector reforms. Financial inclusion in this phase was encouraged mainly by the introduction of SHG-bank linkage programme in the early 1990s and Kisan Credit Cards (KCCs) for providing credit to farmers. In the third phase, beginning in April 2005, 'financial inclusion' was explicitly made as a major policy objective and thrust was on providing safe facility of savings deposits through 'no frills' accounts.

\section{A Glimpse of Extent of Financial Inclusion in the Country}

1. Number of No-Frill Accounts -28.23 million (as on Dec. 31, 2008)

2. Number of rural bank branches $-31,727$ constituting $39.7 \%$ of total bank branches (as of June. 31, 2009)

3. Number of ATMs $-44,857$ (as on May 31, 2009)

4. Number of POS $-4,70,237$ (as on May 31, 2009)

5. Number of Cards -167.09 million (as on May 31, 2009)

6. Number of Kisan Credit cards -76 million

Number of Mobile phones-403 million (as on Apr.30, 2009) out of which 187 million (46\%) do not have a bank account (Table 1).

\section{Observations}

- Less penetration of banks in rural areas is resulted in very high population per branch.

Even though it has come down significantly but population per bank branch is still very high especially in rural areas (Table 2).

\section{Research Methodology}

In order to understand the banking behavior of financially included rural population, Harda and Hoshangabad district is identify as the region of study.

Sample size: Sample of 150 rural people and 6 bank branch managers were taken for the survey. These consist of 2 different districts.

\section{Orientation}

For survey interacted with 150 rural people in covered households, farmers, agricultural and non-agricultural labors, self-employed and others, met all of them personally and spent some time with them discussing both the questionnaire and their experience in the bank. Apart from this 6bank branch's managers also covered in survey.

Through this got a lot of knowledge about their problem, which concerned our survey and also an insight into the effects of HR practices, which will definitely help in the future.

\section{Phases}

There were four phases:

1. Adding new questions in some areas and new area which was not covered previously in the questionnaire of customer's satisfaction and others rural people but which were also crucial.

2. Filling up a questionnaire by meeting everyone personally.

3. Analysis and Interpretation.

4. Suggestions

\section{Methods of Data Collection}

The methodology followed was primary data collection through questionnaire survey and

In-depth interview technique

Two questionnaires were prepared for the study.

- Questionnaire for the bank branches

- Questionnaire for the Rural people

Two questionnaires made one for rural people to know their thinking and knowledge about the bank functions. The second for the banker's to know the banker's perspective of financial inclusion what are the initiatives they take to reach every individual in the villages.

The questionnaire for rural people are contains 26 Questions and is designated in order to get the details related to the financial habit, banking behavior and credit planning. The questionnaire also contains open questions in order to record their views on low usage of bank accounts. The questionnaire is designed with multiple choice and dichotomous questions.

The questionnaire for the Bank Managers contains 15 questions

\begin{tabular}{|c|c|c|c|}
\hline End March & Rural & Urban & Total \\
\hline 1969 & 82 & 33 & 63 \\
\hline 1981 & 20 & 17 & 19 \\
\hline 1991 & 14 & 16 & 14 \\
\hline 2001 & 16 & 15 & 16 \\
\hline 2007 & 17 & 13 & 16 \\
\hline
\end{tabular}

Table 1: Population Per Bank Branch (Scheduled Commercial Banks - Figure in thousands). 
Citation: Pradhan R (2013) Evaluation of Micro Finance in Harda and Hoshangabad Districts of MP. J Glob Econ 1: 103. doi:10.4172/23754389.1000103

Page 4 of 14

\begin{tabular}{|c|c|c|c|c|c|c|c|}
\hline $\begin{array}{c}\text { Region/State/Union } \\
\text { Territory }\end{array}$ & Current Accounts & Savings Accounts & Total Population & $\begin{array}{l}\text { Adult Population } \\
\text { (Above } 19 \text { years) }\end{array}$ & $\begin{array}{l}\text { Total No. Of } \\
\text { accounts }\end{array}$ & $\begin{array}{l}\text { No. of acc. } \\
\text { Per } 100 \text { of } \\
\text { population }\end{array}$ & $\begin{array}{c}\text { No. of acc. Per } \\
100 \text { of adult } \\
\text { pop. }\end{array}$ \\
\hline NORTHERN REGION & 4215701 & 52416125 & 132676462 & 67822312 & 56631826 & 43 & 84 \\
\hline Haryana & 572660 & 8031472 & 21082989 & 11308025 & 8604132 & 41 & 76 \\
\hline Himachal Pradesh & 134285 & 2433595 & 6077248 & 3566886 & 2567880 & 42 & 72 \\
\hline Jammu \& Kashmir & 277529 & 3094790 & 10069917 & 5379594 & 3372319 & 33 & 63 \\
\hline Punjab & 1156137 & 13742201 & 24289296 & 14185190 & 14898338 & 61 & 105 \\
\hline Rajasthan & 689657 & 12139302 & 56473122 & 28473743 & 12828959 & 23 & 45 \\
\hline Chandigarh & 80607 & 1126696 & 900914 & 546171 & 1207303 & 134 & 221 \\
\hline Delhi & 1304826 & 11848069 & 13782976 & 7929589 & 13152895 & 95 & 166 \\
\hline $\begin{array}{l}\text { NORTH-EASTERN } \\
\text { REGION }\end{array}$ & 476603 & 6891081 & 38495089 & 19708982 & 7367684 & 19 & 37 \\
\hline Arunachal Pradesh & 10538 & 209073 & 1091117 & 544582 & 219611 & 20 & 40 \\
\hline Assam & 378729 & 5071058 & 26638407 & 14074393 & 5449787 & 20 & 39 \\
\hline Manipur & 12514 & 200593 & 2388634 & 1222107 & 213107 & 9 & 17 \\
\hline Meghalaya & 24305 & 458779 & 2306069 & 1088165 & 483084 & 21 & 44 \\
\hline Mizoram & 3441 & 117885 & 891058 & 476205 & 121326 & 14 & 25 \\
\hline Nagaland & 13819 & 195452 & 1988636 & 995523 & 209271 & 11 & 21 \\
\hline Tripura & 33257 & 638241 & 3191168 & 1784212 & 671498 & 21 & 38 \\
\hline EASTERN REGION & 1814219 & 47876140 & 227613073 & 122136133 & 49690359 & 22 & 41 \\
\hline Bihar & 464511 & 13225242 & 82878796 & 40934170 & 13689753 & 17 & 33 \\
\hline Jharkhand & 166007 & 5834341 & 26909428 & 13737485 & 6000348 & 22 & 44 \\
\hline Orissa & 228160 & 7030004 & 36706920 & 21065404 & 7258164 & 20 & 34 \\
\hline Sikkim & 4097 & 125365 & 540493 & 288500 & 129462 & 24 & 45 \\
\hline West Bengal & 942733 & 21544753 & 80221171 & 45896914 & 22487486 & 28 & 49 \\
\hline $\begin{array}{l}\text { Andaman \& Nicobar } \\
\text { Islands }\end{array}$ & 8711 & 116435 & 356265 & 213660 & 125146 & 35 & 59 \\
\hline CENTRAL REGION & 2202217 & 64254189 & 255713495 & 129316677 & 66456406 & 26 & 51 \\
\hline Chhattisgarh & 192067 & 3346898 & 20795956 & 11209425 & 3538965 & 17 & 32 \\
\hline Madhya Pradesh & 553381 & 11731918 & 60385118 & 31404990 & 12285299 & 20 & 39 \\
\hline Uttar Pradesh & 1324509 & 45804350 & 166052859 & 82229748 & 47128859 & 28 & 57 \\
\hline Uttaranchal & 132260 & 3371023 & 8479562 & 4472514 & 3503283 & 41 & 78 \\
\hline WESTERN REGION & 3178102 & 49525101 & 149071747 & 86182206 & 52703203 & 35 & 61 \\
\hline Goa & 81551 & 1584177 & 1343998 & 891411 & 1665728 & 124 & 187 \\
\hline Gujarat & 955964 & 16220262 & 50596992 & 28863095 & 17176226 & 34 & 60 \\
\hline Maharashtra & 2127240 & 31568184 & 96752247 & 56207604 & 33695424 & 35 & 60 \\
\hline Dadra \& Nagar Haveli & 6076 & 69308 & 220451 & 122765 & 75384 & 34 & 61 \\
\hline Daman \& Diu & 7271 & 83170 & 158059 & 97331 & 90441 & 57 & 93 \\
\hline SOUTHERN REGION & 4666014 & 83386898 & 223445381 & 135574225 & 88052912 & 39 & 65 \\
\hline Andhra Pradesh & 1156405 & 23974580 & 75727541 & 44231918 & 25130985 & 33 & 57 \\
\hline Karnataka & 1086662 & 19147819 & 52733958 & 30623289 & 20234481 & 38 & 66 \\
\hline Kerala & 600065 & 17669723 & 31838619 & 20560323 & 18269788 & 57 & 89 \\
\hline Tamil Nadu & 1786514 & 22052812 & 62110839 & 39511038 & 23839326 & 38 & 60 \\
\hline Lakshadweep & 491 & 22997 & 60595 & 33686 & 23488 & 39 & 70 \\
\hline Pondicherry & 35877 & 518967 & 973829 & 613971 & 554844 & 57 & 90 \\
\hline ALL-INDIA & 16552856 & 304349534 & 1027015247 & 541031553 & 320902390 & 31 & 59 \\
\hline
\end{tabular}

Table 2: Coverage of Banking Services (Ratio of Demand Deposit Accounts to the adult population).

and it majorly focused on the strategies followed by banks in order to encourage people to open No-Frills accounts and the steps taken by them to motivate frequent bank account usage. This questionnaire majorly contains open questions in order to obtain a descriptive opinion of the Managers.
For this study random sampling is used to survey in different villages.

\section{Procedural Steps Followed By Survey}

- Identification of 6 Bank branches for study in Harda and 
Hoshangabad district.

- Interview with Branch managers

- Identification of villages under the service area

- Random selection of village for study

Interview with the people of villages those have account in different bank and those have not.

Step 1: After designing the questionnaire, the next step was to identify the bank branches in the Harda \& Hoshangabad District that could be taken up for the study. Under the six bank branches were selected so as to geographically cover all the blocks in the District.

Step 2: The identified six branches were visited and the questionnaire was administered to the Bank Managers. This questionnaire majorly contained open questions in order to obtain a descriptive opinion of the Managers

Step 3: Firstly was gone to Harda district and the questionnaire was administered to the bank manger of that area.

Step 4: With the help of the respective Bank Managers, 2 or 3 villages in the service area of the bank was selected for study.

Step 5: After that was went to Hoshangabad district and that area also questionnaire was filled by branch managers and with the help of respective Bank managers some villages in the service area of the bank was selected to study.

Step 6: Totally 6 villages were visited and 150 respondents were interviewed. The

Questionnaire was explained to them in the local language and their answers were recorded in an interview format (Table 3).

\section{Scope of the Study}

- It gives clear picture of financial inclusion in rural areas.

- Improvement in financial inclusion require joint efforts of customer as well as bank

- Government and RBI take many initiatives for the improvement bus there is some gap to meet those steps.

- Bank should be concentrate on customer relationship.

- The survey started asked the respondents:

- The occupation of the respondent, the source of income for the family and whether the respondent had an account, if so the type of account.

- About the awareness of new measures for financial inclusion like no-frills account, GCCs, and relaxation of KYC norms for accounts

- The reason for not opening the account and if aware about measures for Financial Inclusion, the reason for not opening an account.

- Whether they had availed any credit (long term and shortterm) from the banks, and the type of credit that was availed to them by the banks.

- Whether any family member was a part of an SHG or had access to micro credits from MFIs.

- The credit requirements and whether they were interested in availing credit from banks and for what particular reason.

- About Money Lenders (MLs) and Micro Finance Institutions (MFIs) and whether they were dealing with MLs and MFIs. If they had taken any credit from these, then what rate of interest they enquired.

\section{Objectives for the Study}

1. To find that the knowledge about the bank functions and faith on the bank have a correlation.

2. To find that the knowledge about the bank functions and the satisfaction with existing bank has a correlation.

3. To find that the knowledge about the bank functions has a correlation with the satisfaction with the existing bank's employees.

4. To find that the knowledge about the bank functions has a correlation with the required improvement in the bank

5. To find that the knowledge about the bank functions has negative correlation the customer's willingness to open the account in the bank.

6. To find that the knowledge about the bank functions has a correlation with the knowledge about the entire surrounding existing banks, if customers have knowledge about the bank functions so they get stimulated to knowing about the entire surrounding bank.

7. To find that the faith on the bank and the satisfaction with existing bank has a correlation.

8. To find that the faith on the bank and the satisfaction with the existing bank's employees has a correlation.

9. To find that the faith on the bank is positively correlated to the require improvement in the bank.

\begin{tabular}{|c|c|c|c|c|}
\hline S. No. & Bank Name & Block & No. of villages covered by Bank & Villages visited for the survey \\
\hline \multirow{2}{*}{1} & \multirow{2}{*}{ Regional Rural Bank } & \multirow{2}{*}{ Harda } & \multirow{2}{*}{20} & Balagaon \\
\hline & & & & Magarda \\
\hline \multirow{2}{*}{2} & \multirow{2}{*}{ State bank of India } & \multirow{2}{*}{ Harda } & \multirow[t]{2}{*}{15} & Balagaon \\
\hline & & & & Kanarda \\
\hline \multirow[t]{2}{*}{3} & \multirow{2}{*}{ Regional Rural Bank } & \multirow[t]{2}{*}{ Hoshangabad } & \multirow[t]{2}{*}{22} & Rojhara \\
\hline & & & & Shail \\
\hline 4 & $\mathrm{ICICl}$ & Hoshangabad & 8 & Misrode \\
\hline \multirow[t]{2}{*}{5} & \multirow{2}{*}{ State bank of India } & \multirow{2}{*}{ Dolaria } & \multirow{2}{*}{12} & Rojhra \\
\hline & & & & Shail \\
\hline 6 & Central Bank & Dolaria & 9 & Rojhara \\
\hline
\end{tabular}

Table 3: Specifications of banks. 


\section{Hypothesis}

H0a: Knowledge about the bank functions

H1a: Knowledge about the bank functions and faith on the bank have a correlation.

H2a: Knowledge about the bank functions and the satisfaction with existing bank has a correlation.

H3a: Knowledge about the bank functions has a correlated to the satisfaction with the existing bank's employees.

H4a: Knowledge about the bank functions has a correlated to the require improvement in the bank

H5a: Knowledge about the bank functions has a correlated to the customer's willingness to open the account in the bank.

H6a: Knowledge about the bank functions has a correlated to the knowledge about the entire surrounding existing banks

HOb: Faith on the bank

H1b: Faith on the bank and the satisfaction with existing bank are correlated.

H2b: Faith on the bank and the satisfaction with the existing bank's employees are correlated.

$\mathrm{H} 3 \mathrm{~b}$ : Faith on the bank has a correlated to the require improvement in the bank

H4b: Faith on the bank has a correlated to the customer's willingness to open the account in the bank

H5b: Faith on the bank has a correlated to the knowledge about the entire surrounding existing banks.

H0c: Satisfaction with the exiting bank

H1c: Satisfaction with the existing bank and the satisfaction with the bank's employees have a correlated.

$\mathrm{H} 2 \mathrm{c}$ : Satisfaction with the existing bank and the require improvement in the bank have a correlated.

H3c: Satisfaction with the existing bank and the customer's willingness to open the account in the bank has a correlated.

H4c: Satisfaction with the existing bank and the knowledge about the entire surrounding existing banks has a correlated

H0d: Satisfaction with the existing bank's employees

H1d: Satisfaction with the existing bank's employees and the require improvement in the bank have a correlated

H2d: Satisfaction with the existing bank's employees has a correlated to the customer's willingness to open the account in the bank

H3d: Satisfaction with the existing bank's employees and the knowledge about the entire surrounding existing bank has a correlated.

H0e: Require improvement in the bank

H1e: Require improvement in the bank and the Customer's willingness to open account in the bank have a correlated

$\mathrm{H} 2 \mathrm{e}$ : Require improvement in the bank and the knowledge about the entire surrounding existing banks has a correlated.

H0f: Customers willingness to open the account
H1f: Customer's willingness to open the account in the bank the knowledge about the entire surrounding existing bank has a correlated.

\section{Correlation}

Correlation was used to prove this hypothesis, when we are interesting in measuring the degree of relationship between two variables, we use concept, i.e. coefficient of correlation.

$$
r=\frac{N \sum x y-\left(\sum x\right)\left(\sum y\right)}{\left.\sqrt{\left[N \sum x^{2}\right.}-\left(\sum x\right)^{2}\right]\left[N \sum y^{2}-\left(\sum y\right)^{2}\right]}
$$

Where:

$\mathrm{N}=$ number of pairs of scores

$\sum x y=$ sum of products of paired scores

$\sum x=$ sum of $\mathrm{x}$ scores

$\sum y=$ sum of y scores

$\sum x^{2}=$ sum of squared $\mathrm{x}$ scores

$\sum y^{2}=$ sum of squared y scores

\section{Reason for using Likert Scale}

Likert scale of five-point Likert item is used to know the highest number of respondents that they agree to same factor, it also show customers attitude towards the banks, Likert Scale is very effective tool to know what is important factor that all the respondents have to agree on it.

\section{Steps for likert scale}

- After questionnaires were filled by the respondents now all the data is analyze with likert scale, for this all the data fitted into excel.

- Than selects the questions where likert scale apply and all the responses scale according as give very low-1, low-2, moderate- 3 , highly- 4 , very high- 5 used five point scaling technique.

- Than evaluate in each questions how much responses were given to each scaling item, like number of responses for a particular questions give response for very low, low, moderate and so on.

- After that take mean of every question and than multiply each scaling item with number of responses, and check in all the questions highest number of responses for scaling item.

Answer is that factor in which have highest no. of scaling point, and this shows that the most of the people want or agree for the same scaling item.

\section{Observation \& Findings}

\section{Observation}

A total of 150 respondents were randomly selected from 6 different villages for the survey (Figure 1).

- Only the primary data collected through the interview is use for the analysis 
Citation: Pradhan R (2013) Evaluation of Micro Finance in Harda and Hoshangabad Districts of MP. J Glob Econ 1: 103. doi:10.4172/23754389.1000103

Page 7 of 14

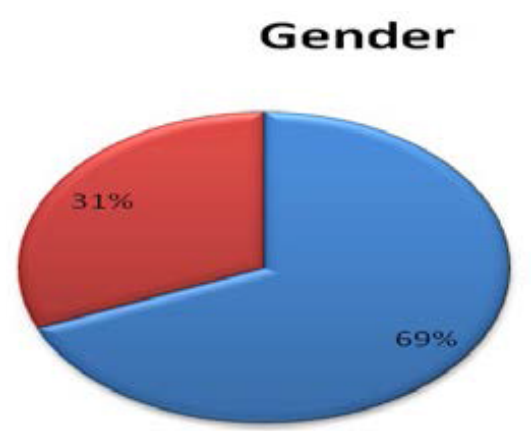

Figure 1: Obsevation.

- The sample composed of $69 \%$ male and $31 \%$ female respondents.

- The sample contains more female than male because in majority of the household women showed more interest to open a bank account for saving compared to male member. Moreover more female registered themselves with the NREGS and hence possessed Bank passbooks.

\section{Education level}

- About $43 \%$ of the respondents did not have proper schooling (Figure 2).

- $31 \%$ of them had education till 5th Grade and 19 of the respondents had schooling till 12th grade.

- It was also seen that $6 \%$ of the respondents were graduates and completed technical studies like welding, tailoring, teacher training etc.

\section{Occupations of the respondents}

- A majority of the respondents 52 were agricultural and nonagricultural labors who were also registered for the NREGS. They have opened the bank account after it was made mandatory for the NREGS jobs (Figure 3).

- 69 of them were farmers who owned cultivatable land.

- Around 5 of them worked in public/private sectors and these set of people were involved in active savings through the saving schemes sponsored by the organization they work in. and 5 people are in private business and 4 are self- employed.

- About 15 of them were Housewives, students and unemployed.

\section{Agewise distributions of respondents}

- A majority of respondents belong to age group 35to60.

- 60 people belong to 18to35 age group (Figure 4).

- 12 are above the age 60 .

- 3are in the age group of 10 to 18 .

\section{Income levels of respondents}

- 76 people annual income less than 30000 they are basically agriculture and non-agri labours (Figure 5).

- 56 peoples have annual income between 30000to80000Rs.

- 16 peoples have annual income between 80000to1.5lacs and there are 2 people who belong to income group 1.5lacs to2.5lacs and more than 2.5lacs respectively.

\section{Earning pattern of respondents}

- 62 respondents are earning on daily basis they are agricultural and non-agricultural labours (Figure 6).

- 51 respondents are earning on semi-annual basis they are basically farmer.

- 18 respondents are earning on monthly and 19 respondents on annual basis.

\section{Saving habits of the respondents}

- $39 \%$ respondents save some part of their income (Figure 7).

- $52 \%$ respondents do not save a part on their income basically

\section{Education Level Of People}
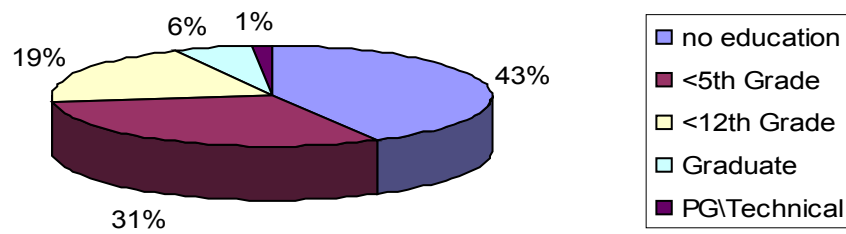

Figure 2: Education level.

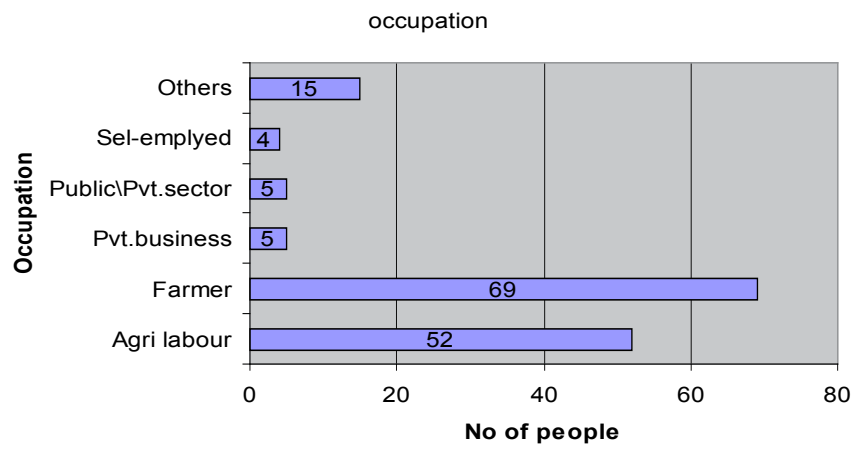

Figure 3: Occupations of the respondents.

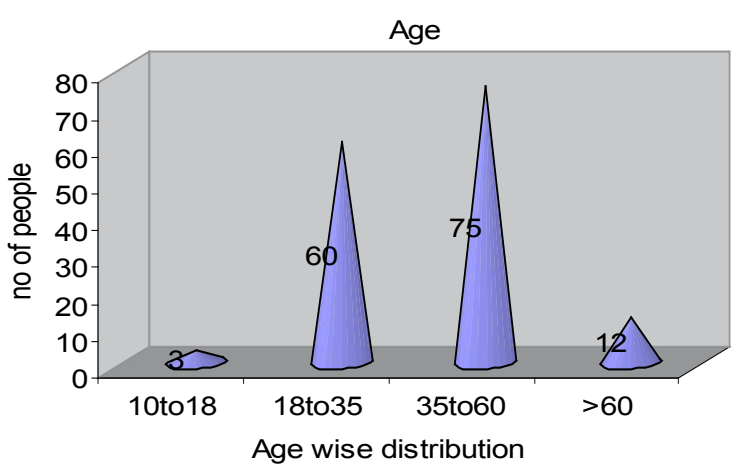

Figure 4: Agewise distributions of respondents. 
Citation: Pradhan R (2013) Evaluation of Micro Finance in Harda and Hoshangabad Districts of MP. J Glob Econ 1: 103. doi:10.4172/23754389.1000103

\section{Income level of Respondents}

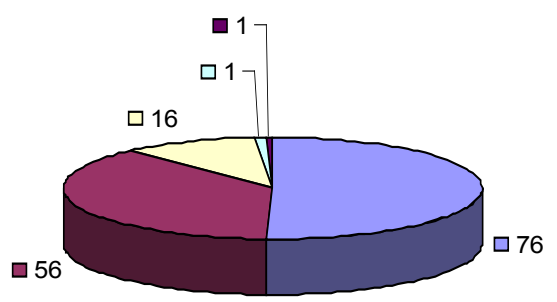

Figure 5: Income levels of respondents.

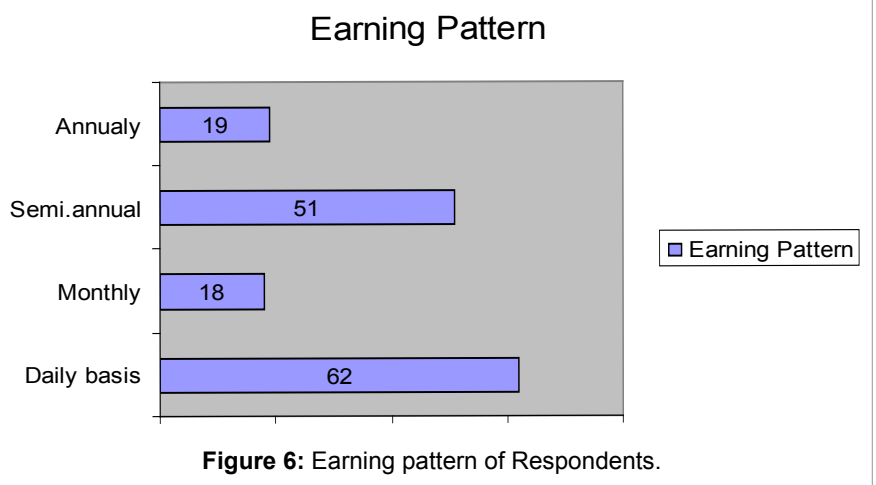

Saving Habit of Respondents

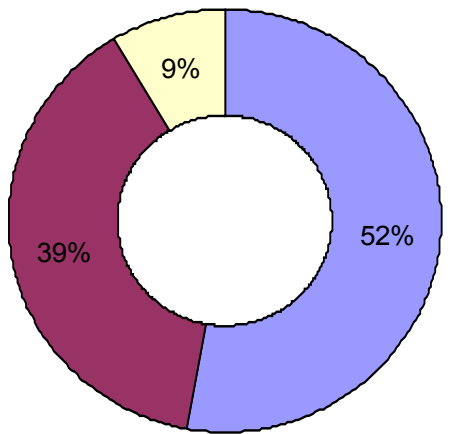

Figure 7: Saving habits of the respondents.

they are agri and non-agricultural labours who have earned very less income and some are other people have sufficient income but they don't have saving habits.

- $9 \%$ people don't reply this question.

\section{Types of services \products use along with bank account}

- $50 \%$ respondents use account for payments \&remittance (Figure 8).

- $19 \%$ respondents take loan from the bank.

- $22 \%$ people use KCC-kisan credit card, 7\%use ATM $\backslash$ debit card, $1 \%$ use mobile banking and $1 \%$ use credit card.

\section{Keep saving}

- Around half of the respondents (97of 150) said that they have been doing savings by Keeping it in their house. The inference of this habit is that the people lack in financial literacy and they are ignorant about other means of doing savings (Figure 9).

- Only 41 respondents were doing savings through banks.

- Self Help Groups play a major role in imbibing savings habit in the people.

- 5 respondents said that Post Office was their preferable source because they were located within their village premises.

- LIC/Insurance was said to be the preferable source of saving by 1 respondent. The main reason was that the LIC agent who usually used to be a relative or friend of the individual goes to the doorsteps to collect the premium amount.

- Cooperative societies were found be the preferable source of saving for 5 respondents mainly due to their accessibility.

- Some factories have also given a provision to save a few amount of money in their own savings scheme. This has got a positive response because the workers in the factory can save a small amount of their wages from the place where they get the wages.

\section{Account in the bank}

- $44 \%$ respondents have account in the Regional rural bank (Figure 10).

- $30 \%$ respondents have account in the state bank of India.

\section{Types of services IProducts use by customers}

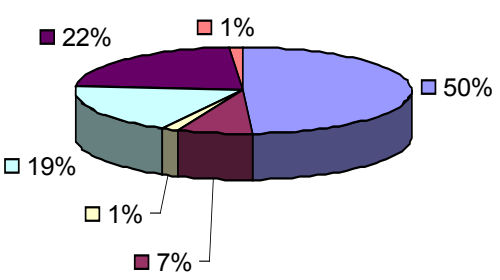

$\square$ Paymenrt\&remittance

$\square$ ATMIDebit card

$\square$ Mobile banking

$\square$ Loan\&advances

$\square \mathrm{KCC}$

$\square$ Credit card

Figure 8: Types of services Iproducts use along with bank account.

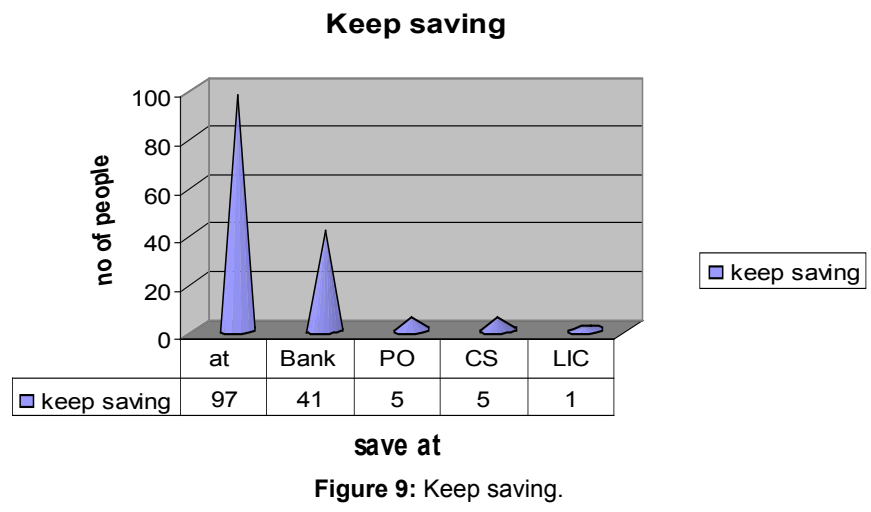


Citation: Pradhan R (2013) Evaluation of Micro Finance in Harda and Hoshangabad Districts of MP. J Glob Econ 1: 103. doi:10.4172/23754389.1000103

\section{Accont in the bank}

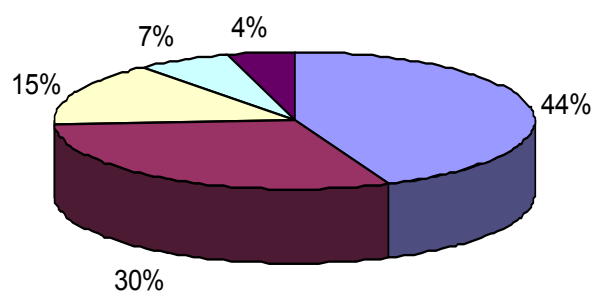

Figure 10: Account in the bank.

- $15 \%$ respondents have account in the central bank, $7 \%$ have account in the ICICI bank and $4 \%$ people have account in the others bank like-Punjab national bank, Bank of India etc.

\section{Distance of the bank from their residence}

- 17 people's residence have $0-5 \mathrm{~km}$ from the bank (Figure 11 ).

- 40 people have distance between their bank and their home is $5-10 \mathrm{~km}$.

- 86 people have distance between their bank and their home is $10-15 \mathrm{~km}$.

- 7 people have bank more than $15 \mathrm{~km}$ from their home.

\section{Purpose of using account}

- $56 \%$ said that they use account for deposing\& withdrawing money for cash flow managed.

- $18 \%$ use account for making \&receiving payments. (Figure 12).

- $15 \%$ said they use account for accumulating funds and interest earning.

- $11 \%$ said they use account for to become eligible for other services, so basically these are the target customer for the bank.

\section{Purpose of borrowing}

- $61 \%$ respondents borrow money for funding agriculturel business (Figure 13).

- $33 \%$ respondents borrow for personal (food, clothing, celebration or social obligation. To repay old debts)

- $3 \%$ people borrow for residential house purchase and $3 \%$ people borrow for education of children.

\section{Sources of borrowing for respondents}

- 71respondents borrow from money lenders, 44 from bank, and 23 from friends $\backslash$ relatives (Figure 14).

- Only 9 people borrow from cooperative society and 3 people from NGOs $\backslash$ SHGs.

In spite of the fact that the Money lenders charge a higher interest rate, a large population prefers to borrow from them. Respondents who borrowed from the Money lenders were asked the reason for borrowing from Money lenders. Majority of the people (48\% of the respondents) depend on Money lenders because they have no other means of getting credit. Lesser procedure and documentation involved is another attraction for availing the Money lenders service. A Money lender typically does a Spot payment with Zero documentation. Availability of cash at the time of emergency is the reason for the choice of $12 \%$ of the respondents. Mostly when the cash needs arise out of medical emergency, it is met only by the Money lenders as they ask for no documents or surety and gives the cash in hand. Location criteria and anytime access of cash are other reasons for borrowing from Money lenders.

\section{Distance of the bank from the residance}

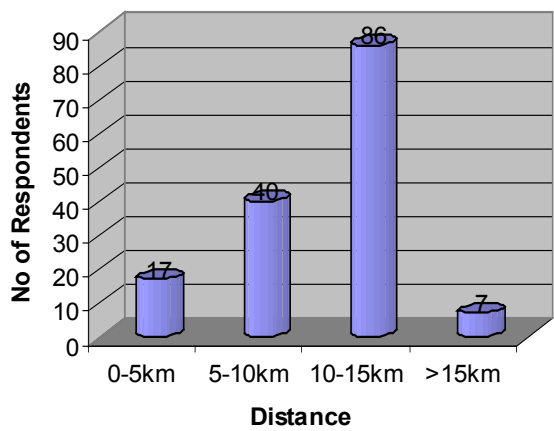

distance of the bank

Figure 11: Distance of the bank from their residence.

\section{Purpose of using account}

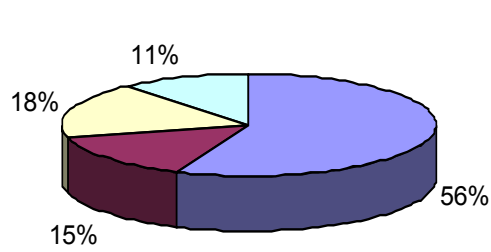

$\square$ Deposing\& withdrawing

$\square$ Accumlating fundslinterest earning

$\square$ Making\&receiving payment

$\square$ to become eligible for other services

Figure 12: Purpose of using account.

\section{Purpose of Borrowing}

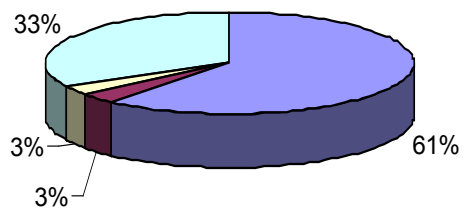

$\square$ For funding agriculture
$\square$ Residential house
purchase
$\square$ Education of children
$\square$ Personal

Figure 13: Purpose of borrowing. 


\section{Sources of Borrowing}

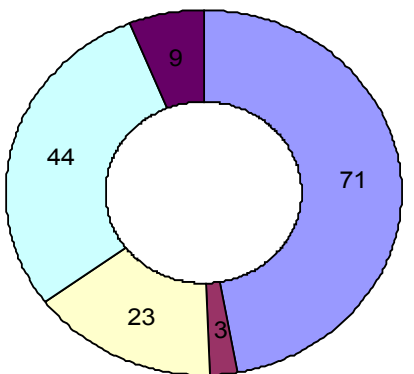

Figure 14: Sources of borrowing for Respondents.

\section{Frequency of usage account holder}

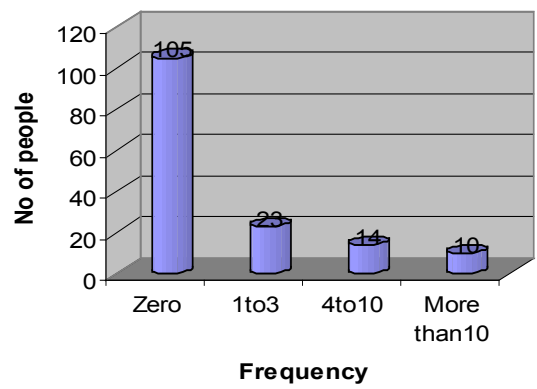

Figure 15: Frequency of usage of account holder.

\section{Frequency of usage of account holder}

- 105 people don't use account, 23 people use only 1to3time their account (Figure 15).

- 14 people use 4 to 10 time account and only 10 people use their account more than 10 times.

\section{Reasons for poor usage of bank account}

- A total of 105 respondents whose bank account usage was minimum were interviewed the reason for poor usage.

- Bank's location was the reason constraint for the majority of the respondents (40respondents).

- Equally contributing is that people have the perception that small amounts cannot be saved in banks. Even among the respondents the practice was to save small amount in their house and depositing the saved money in the bank once in a month. In this process, they tend to spend the saved money for consumption needs.

- 25 respondents felt that the complex process involved in the transaction was the reason for their poor usage.

- In few villages, it was observed that even after the No-Frills accounts were opened, they were not provided with the Bank passbooks. As they have no means of connection with the bank, they tend to be detached from the bank.

- 30 respondents felt that they have no awareness about the banking services.
- Banks officials response for queries and the Bank's functioning time were other reasons for the poor usage

\section{Preferred bank by the respondents}

- 131 respondents said if the open the account in the bank so they preferred Government bank and only 19 respondents said that they preferred Private sector bank.

- So this shows that people like to open account in the government sector bank like: SBI, PNB etc (Figure 16).

- So the Government banks have more penetration than the private sector bank.

\section{Banker's perspective of financial inclusion}

1. Banks have relaxed the KYC norms for account opening. They open the account for a person if he/she has identified prove of their residence.

2. Business facilitators play crucial role in to increase bank ability to reach individuals.

3. Local NGOs and the Self help group (SHGs) have played a major role in communicating the village people about the account opening and for coordinating them to the banks. They have also volunteered in account opening work.

4. Door to door campaign has been used by the bank in some villages in order to communicate and create publicity about opening bank account. Pre survey was also used as a chance to meet people in the village and communicate the need for opening bank account.

5. Number of announcement was made in the streets of the village to communicate the gathering point for account opening formalities. These announcements are made either in the evening or in the early morning when the people are available in their house.

6. Banks have opened account opening centers at common places on Sunday where people gather at the aforesaid time which helped the banks to do a bulk processing of account opening.

7. Bank Managers felt that the bank account opening drive has gained momentum after making it mandatory for NREGS jobs. In some banks, the number of No-Frills account were calculated based on the number of NREGS job cards issued in their service area.

8. As of now, funds of Government schemes are not credited

\section{Prefered Bank by the respondents}

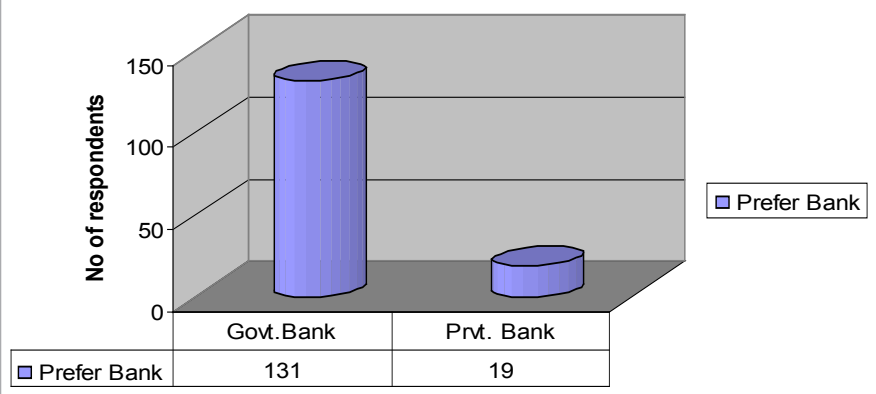

Figure 16: Banker's perspective of financial inclusion. 
directly into the individual's account. They are either paid in the form of cash or as a crossed cheque. People step into bank mainly for availing services like Gold loan and for collection of issued by Government schemes.

9. Benefits that the banks enjoy after the Financial Inclusion drive.

- Increase in customer base and higher foot falls in the banks.

- Increase in the floating deposit base.

- Variety in the portfolio of the bank's credit.

- Greater utilization of the Gold Loan facility.

10. Private bank's participation in the Financial Inclusion is found to be very less.

11. Banks have not taken any initiative to impart financial literacy. They help out the people who enter the bank by assisting them in filling up the forms and guiding them to the right place.

\section{The broad strategy for financial inclusion in rural areas is comprises the following elements}

1. Encouraging penetration into unbanked and backward areas and encouraging agents and intermediaries such as NGO's, MFI's, CSO's and business correspondents (BC's).

2. Focusing on a decentralized strategy by using existing arrangements such as State Level Bankers' Committee (SLBC) and district consultative committee (DCC) and strengthening local institutions such as co-operatives and RRB's.

3. Using technology for furthering financial inclusion.

4. Advising banks to open a basic banking 'no frills' account.

5. Emphasis on financial literacy and credit counseling.

6. Creating synergies between the formal and informal segments.

\section{Data Analysis}

\section{Correlation analysis}

When we are interesting in measuring the degree of relationship between two variables, we use concept, i.e. coefficient of correlation.

Above correlation results show that the hypothesis H1a: Knowledge about the bank functions and faith on the bank have a correlation and as the customer's knowledge about the bank increases, their faith on the bank also increases and so banks should make the strategies to educate the people for banking functions which in turn increase faith over the bank (Table 4).

- Above correlation value shows that the Hypothesis H2a: Knowledge about the bank functions and the satisfaction with existing bank has a correlation. If the knowledge about the bank functions increases it in turn increases customer's satisfactions towards the bank.

- Correlation value shows that the Hypothesis H3a: Knowledge about the bank functions has a correlation with the satisfaction with the existing bank's employees and has a positive correlation

- Hypothesis H4a: Knowledge about the bank functions has a correlation with the required improvement in the bank, its shows relationship between both the factors.
- Above correlation value is negative this proves that the hypothesis $\mathrm{H} 5 \mathrm{a}$ : knowledge about the bank functions has negative correlation the customer's willingness to open the account in the bank. When one factor increases the other factor decreases and vice-versa.

Correlation value shows positive correlation between the factors and Hypothesis H6a: Knowledge about the bank functions has a correlation with the knowledge about the entire surrounding existing banks, if customers have knowledge about the bank functions so they stimuli to knowing about the entire surrounding bank (Table 5).

- Faith on the bank and the satisfaction with existing bank has a correlation, this means faith increases over the bank if customers are satisfied with the bank.

- Faith on the bank and the satisfaction with the existing bank's employees has a correlation, if banks concentrate more on customer-relationship so customer's faith on the bank increases.

- Above correlation show that H2b: Faith on the bank has a positive correlated to the require improvement in the bank.

- Faith on the bank has a positive correlation with the customer's willingness to open the account in the bank and this show that if customers have trust over the bank, they want to open the account in the bank, so bankers should make the strategies for increasing trust over the bank.

- Faith on the bank has a correlation with the knowledge about the surrounding existing banks (Table 6).

- H1c: Satisfaction with the existing bank and the satisfaction with the bank's employees have a correlation and this show positive correlation between these two factors. Customer's satisfaction towards the employee increases so satisfaction towards the bank also increases and vice-versa.

\begin{tabular}{|c|c|}
\hline Hypothesis & Correlation \\
\hline $\mathrm{H} 1 \mathrm{a}$ & 0.729614528 \\
\hline $\mathrm{H} 2 \mathrm{a}$ & 0.476581627 \\
\hline $\mathrm{H} 3 \mathrm{a}$ & 0.205582157 \\
\hline $\mathrm{H} 4 \mathrm{a}$ & 0.189805175 \\
\hline $\mathrm{H} 5 \mathrm{a}$ & -0.010966248 \\
\hline $\mathrm{H} 6 \mathrm{a}$ & 0.292353876 \\
\hline
\end{tabular}

Table 4: Result of Correlation.

\begin{tabular}{|c|c|}
\hline Hypothesis & Correlation \\
\hline H1b & 0.652004092 \\
\hline H2b & 0.31255913 \\
\hline H3b & 0.197801044 \\
\hline H4b & 0.04217646 \\
\hline H5b & 0.169148729 \\
\hline
\end{tabular}

Table 5: Result of Correlation.

\begin{tabular}{|c|c|}
\hline Hypothesis & Correlation \\
\hline $\mathrm{H} 1 \mathrm{c}$ & 0.595420815 \\
\hline $\mathrm{H} 2 \mathrm{c}$ & 0.233576573 \\
\hline $\mathrm{H} 3 \mathrm{c}$ & 0.004973186 \\
\hline $\mathrm{H} 4 \mathrm{c}$ & 0.165798417 \\
\hline \multicolumn{2}{|c|}{ Table 6: Result of Correlation. } \\
\hline
\end{tabular}


- H2c: Satisfaction with the existing bank and the require improvement in the bank have a correlation

- H3c: Satisfaction with the existing bank and the customer's willingness to open the account in the bank has a correlation, if satisfaction of the customers towards the bank increases they get stimulated to open more account in the bank like they open the accounts of other family members also.

- H4c: Satisfaction with the existing bank and the knowledge about the surrounding existing banks has a correlation, if knowledge about the surrounding existing banks increases so customers are able to make comparison between the existing bank and other banks and this will increase their level of satisfaction level from the bank (Table 7).

- H1d: Satisfaction with the existing bank's employees and require improvement in the bank have a positive correlation.

- H2d: Satisfaction with the existing bank's employees has a positive correlation with the customer's willingness to open an account in the bank.

- H3d: Satisfaction with the existing bank's employees and the knowledge about the entire surrounding existing banks has a correlation, the result show positive relation between these two factors (Table 8).

- H1e: Required improvement in the bank and the Customer's willingness to open account in the bank have a positive correlation.

- H2e: Required improvement in the bank and the knowledge about the surrounding existing banks has a correlation, means if customers require improvement in the bank so they search other surrounding banks, so bankers have to improve the branch according to the customer requirement otherwise they switch over the bank.

- H1f: Customer's willingness to open an account in the bank, the knowledge about the surrounding existing banks has a negative correlation and both the factors affect each other adversely.

\section{Suggestion}

This test shows that how different factors correlate to each other and among all the factors the most correlated factor is- knowledge about the function of the bank have relation with the trust over the bank (Correlation-0.729614528).

\section{Suggestion for the bank}

- Banks have to adopt promotional strategies for marketing or enhance their business and by which people will get knowledge about the bank functions.

\begin{tabular}{|c|c|}
\hline Hypothesis & Correlation \\
\hline H1d & 0.171645219 \\
\hline H2d & 0.15423669 \\
\hline H3d & 0.197124681 \\
\hline
\end{tabular}

Table 7: Result of Correlation.

\begin{tabular}{|c|c|}
\hline Hypothesis & Correlation \\
\hline $\mathrm{H} 1 \mathrm{e}$ & 0.069139705 \\
\hline $\mathrm{H} 2 \mathrm{e}$ & 0.199834188 \\
\hline $\mathrm{H} 1 \mathrm{f}$ & -0.002049391 \\
\hline
\end{tabular}

Table 8: Result of Correlation.
- Trust over the bank has increase when people have knowledge about banking facilities and services.

- Satisfaction for the bank increase when customers have satisfied with the bank's employees so bank should be concentrate on the customer relations, and it will also increase the trust level of the customer for the bank.

- When people have all the surrounding area's bank knowledge so they want improvement in their existing bank because they are able to compare their bank with the other bank facilities.

- When bank provide better facilities against the money lender and cooperative society so they are highly want to open the account in the bank, so banks should be concentrate on these factors.

\section{Likert scale}

To applying this scale in the data the results are:

Likert scale: Very low-1, Low-2, Moderate-3, Highly-4, Very high5 (Table 9).

\section{According to respondent's answers results are}

\section{Result}

According to Likert scale 312 point or 78 people highly want to start open account in the bank. Mean is also high in the questions where people want to open account in the bank that is-3.70.

\section{Suggestions}

Following suggestion for the banks to improve financial inclusion in rural areas:

- It was observed that there is lot of potential for implementing the Business Correspondent as there is lot of willingness shown by the people to save. Implementation of this model benefits the account holders as well as the bankers to a greater extent.

- Special Awareness and outreach activities should be conducted to educate the various aspects of personal finance planning and about using the bank account.

- As soon as the account is opened, passbooks have to be issued to the accountholders. In some cases it was observed that either passbooks were not issued or the issued passbooks did not reach the beneficiaries.

- Many account holders were not even aware of the purpose of opening the bank account and having passbook. They were under the impression that holding a bank passbook might entail them to have some assistance through Government schemes or result in getting loans in the later stage. Banks have to take necessary action on this perception by constantly reaching out to the villages and stress upon the need for saving.

- Any letter communication from the banks should be addressed in the local language.

- Routing the Government Scheme funds is one of the efficient ways to control theleakage of funds through intermediaries as the funds reach the beneficiaries directly. But before implementing the direct crediting of money into the beneficiaries 'accounts it is very important to make sure everybody in the district possess bank accounts. 


\begin{tabular}{|c|c|c|c|c|c|}
\hline Questions & Very Low (1) & Low (2) & Moderate (3) & Highly (4) & Very High (5) \\
\hline 1. Knowledge about the bank functions and loans & 29 & 98 & 111 & 96 & 55 \\
\hline 2. Trust over the bank & 4 & 36 & 231 & 132 & 90 \\
\hline 3. Satisfied with the existing bank & 2 & 50 & 225 & 116 & 45 \\
\hline 4. Satisfied with the bank's employees & 2 & 48 & 294 & 88 & 20 \\
\hline 5. Require improvement in the bank & 0 & 34 & 306 & 96 & 20 \\
\hline 6. Would mind to open the account in the bank & 0 & 6 & 162 & 312 & 75 \\
\hline 7. Knowledge about the entire surrounding existing bank & 15 & 100 & 159 & 112 & 20 \\
\hline
\end{tabular}

Table 9: Likert Scale applied to data.

- As majority of the population feel that banks are located far from their residence, it is very important to take the banking services to their doorsteps. It has to be clearly understood that this is a "Push Market" and the banks have to reach out to them to initialize the banking habits in them.

- Though the present active account users are very low, they can be effectively used to propaganda the need for saving. "Word of Mouth" will be an effective medium to communicate this message.

- Banks have to work in the convenient hours for labourers as most of them go to work early in the morning and come back at around $6 \mathrm{pm}$. Banks have to allocate a specific time in the evening especially to meet the needs of the labourers.

- Banks should leverage technology to the maximum to induce the new accountholders to use and transact the accounts more and save more.

- Best practices followed by a bank for some specific problem has to be documented and shared among other banks within the district on a periodic basis.

- External Agencies may be employed to make a post implementation survey in the region and the feedback on the situation at the ground level may be shared.

- District Administration and Lead Bank has to take necessary steps to conduct workshops to sensitize the banks, NGOs, $\mathrm{BC} / \mathrm{BFs}$ and other parties involved on the need for effective utilization of bank accounts.

- Bank Branches have to be financially helped in upgrading the infrastructure requirements and to meet the man power shortage. The banks that are performing better in Financial Inclusion may be incentives through infrastructure support from RBI.

- Bankers have to make a field visit to their service area to have a better understanding of the customer's needs. This also enables the Bankers to sensitized financial situation of the people.

\section{Conclusion}

Steps taken towards bringing lower income groups to the banking system has been successful to a significant extent, as the main causes observed earlier like distance of bank branch, unawareness about banking services has improved. While doing survey it was found that people are not voluntarily excluding themselves from banking system, most of them have faith in banking and feels that they need banking services. The need varies from managing cash flow as they earn on daily basis or irregular basis. The reasons behind not approaching banks are mainly the minimum balance requirements which have been taken care by No Frills Bank Account but most of the respondent was not aware about this type of account. Hence it needs to be advertised; literacy level and awareness about various other products/services. It was also found that people prefer to borrow from personal/informal sources when the purpose is personal or consumption. Where the amount to be borrowed is generally small, the people found to be reluctant to approach banks, whereas for other productive purposes they borrow from banks. In other words, it may be said as per the study conducted in Harda and Hoshangabad district Area. Despite the thrust given to financial inclusion, the desired results have not come up. The banks would have to evolve specific strategies to expand the outreach of their services in order to promote financial inclusion. One of the ways in which this can be achieved in a cost-effective manner is through forging linkages with microfinance institutions and local communities To sum up, banks need to redesign their business strategies to incorporate specific plans to promote financial inclusion of low income group treating it both a business opportunity as well as a corporate social responsibility. They have to make use of all available resources including technology and expertise available with them as well as the MFIs and NGOs. It may appear in the first instance that taking banking to the sections constituting "the bottom of the pyramid", may not be profitable but it should always be remembered that even the relatively low margins on high volumes can be a very profitable proposition. Financial inclusion can emerge as commercial profitable business.

\section{References}

1. Naveen Shetty K (20005) The Microfinance Promise in Financial Inclusion and Welfare of the Poor: Evidence from India. NSSO, 2004-05 (61st round).

2. Aduda J, Elizabeth K (2012) Financial Inclusion and Financial Sector Stability With Reference To Kenya: A Review of Literature. Journal of Applied Finance \& Banking 2: 95-120

3. Mandira S, Jesim P (2008) Financial Inclusion and Development A Cross Country Analysis. Indian Council for Research in International Economic Relations (ICRIER), New Delhi.

4. Mandira Sarma (2008) Index of Financial Inclusion. Indian Council for Research on International Economic Relation.

5. Umesh CS, Karmakar KG (2009) The Microfinance Review. Journal of the Centre for Microfinance Research.

6. Minakshi Ramji (2009) Financial Inclusion in Gulbarga: Finding Usage in Access. Institute for Financial Management and Research. Centre for Micro Finance. Working Paper Series No 26.

7. Jovi CD, Bienvenido N, Buensuceso P (2011) Microfinance, Financial Inclusion and Financial Development: An Empirical Investigation with an International Perspective. University of Asia and the Pacific.

8. Pokhriyal AK, Vipin G (2011) Progress of Microfinance and Financial Inclusion "A Critical Analysis of SHG-Bank Linkage Program in India.

9. Dharen Kumar, Mukesh Kumar (2011) Microfinance as a Tool for Financing Inclusion. EXCEL International Journal of Multidisciplinary Management Studies.

10. Bharat $P$ (2010) Role of Micro finance Intervention in financial Inclusion: A comparative Study of Microfinance Models. A.J. Institute of Management (AJIM).

11. Mahalaxmi Krishnan Micro Finance through Self Help Groups for Inclusive Growth. 
Citation: Pradhan R (2013) Evaluation of Micro Finance in Harda and Hoshangabad Districts of MP. J Glob Econ 1: 103. doi:10.4172/23754389.1000103

Page 14 of 14

12. Christabell PJ, Vimal Raj A (2012) Financial Inclusion in Rural India: The role of Microfinance as a Tool. IOSR Journal of Humanities and Social Science (JHSS) 2: 21-25

13. Asli DK, Leora K (2013) Measuring Financial Inclusion Explaining Variation Across and Within Countries. Final Conference Draft to be presented at the Spring 2013 Brookings Panel on Economic Activity

14. Purnima K, Surekha N (2012) Workshop on Measuring Financial Inclusion from the Demand Side. Centre for Advanced Financial Research and Learning.
15. Vighneswara Swamy PM (2011) Financial Inclusion in India: An Evaluation of the Coverage, Progress and Trends. The IUP Journal of Financial 8 Economics 2:7-26.

16. Asli DK, Leora K (2012) Measuring Financial Inclusion: The Global Findex Database. Policy Research Working Paper 6025. The World Bank Development Research Group Finance and Private Sector Development Team. 